\title{
Koksidiosis pada sapi perah di Kabupaten Jember, Jawa Timur - Indonesia
}

\section{Dairy cattle coccidiosis in Jember District, East Java - Indonesia}

\author{
Nur Muhamad ${ }^{1 *}$, Aan Awaludin ${ }^{1}$, dan Yudhi Ratna Nugraheni ${ }^{2}$ \\ ${ }^{1}$ Jurusan Peternakan, Politeknik Negeri Jember. Jl. Mastrip Kotak pos 164 Jember, Jawa Timur 68101 \\ ${ }^{2}$ Fakultas Kedokteran Hewan, Universitas Gadjah Mada. Jl. Fauna No 2 Catur Tunggal, Depok, Sleman, Daerah \\ Istimewa Yogyakarta 55283 \\ *Email Koresponden: nurmuhamad@polije.ac.id
}

\begin{tabular}{|c|c|}
\hline ARTICLE INFO & A B S T R A K \\
\hline $\begin{array}{l}\text { Received: } \\
15 \text { February } 2021\end{array}$ & $\begin{array}{l}\text { Penelitian ini bertujuan untuk mengetahui kejadian koksidiosis pada ternak } \\
\text { sapi perah di Kabupaten Jember. Sebanyak } 75 \text { sampel diperoleh dari sapi perah }\end{array}$ \\
\hline $\begin{array}{l}\text { Accepted: } \\
23 \text { March } 2021\end{array}$ & $\begin{array}{l}\text { Friesian Holstein berjenis kelamin betina dengan umur yang bervariasi. Bahan } \\
\text { yang digunakan berupa sampel feses, garam jenuh (Natrium Clorida jenuh), }\end{array}$ \\
\hline $\begin{array}{l}\text { Published: } \\
31 \text { March } 2021\end{array}$ & $\begin{array}{l}\text { dan akuades. Metode yang digunakan adalah metode kuantitatif dengan teknik } \\
\text { Mc. Master dan Whitlock untuk menghitung oosista per gram tinja (OPG) yang } \\
\text { ditemukan dalam sampel untuk mengetahui derajat keparahan koksidiosis. Sampel } \\
\text { feses diambil langsung dari rektum ternak sapi perah atau diambil dari lantai } \\
\text { kandang apabila sapi perah baru saja mengeluarkan feses (feses segar). Sampel }\end{array}$ \\
\hline Kata kunci: & feses yang diambil untuk setiap sapi perah adalah 10 gram feses. Identifikasi oosista \\
\hline Eimeria spp. & Eimeria spp. dilakukan secara kualitatif dengan menggunakan metode apung atau \\
\hline Koksidiosis & flotation method. Data yang diperoleh dianalisis menggunakan analisis deskriptif, \\
\hline Oosista & selanjutnya dilakukan perhitungan prevalensi. Hasil penelitian menunjukkan \\
\hline Parasit & bahwa prevalensi koksidiosis di Kabupaten Jember mencapai $20 \%$ dengan derajat \\
\hline Sapi perah & infeksi kategori ringan. \\
\hline
\end{tabular}

\section{A B S T R A C T}

This study aims to determine the incidence of coccidiosis in dairy cattle in the Jember District. A total of 75 samples were obtained from Friesian Holstein female dairy cows of varying ages. The materials used were fecal samples, saturated salt (saturated sodium chloride), and distilled water. The method used is a quantitative method with the Mc technique. Master and Whitlock to count oocysts per gram of stool (OPG) found in samples to determine the severity of coccidiosis. Stool samples are taken directly from the rectum of the dairy cattle or taken from the floor of the pen if the dairy cows

Key words: Eimeria spp. Coccidiosis Oocysts Parasite Dairy cattle have just released feces (fresh feces). The stool sample taken for each dairy cow is 10 grams of feces. Identification of the oocysts of Eimeria spp. done qualitatively by using the floating method or the flotation method. The data obtained were analyzed using descriptive analysis, then the prevalance was calculated. The results showed that the prevalence of coccidiosis in the Jember District reached 20\% with a mild category of infection.

\section{PENDAHULUAN}

Koksidiosis yang disebabkan oleh protozoa dari genus Eimeria merupakan salah satu penyakit parasitik yang menyerang pada ternak sapi. Koksidiosis merupakan penyakit parasitik dari spesies Eimeria spp. yang menyerang peternakan sapi dengan gangguan kesehatan yang dijumpai pada saluran pencernaan (Lassen, Lepik, \& Järvis, 2014). Eimeria spp. adalah parasit dari kelompok protozoa yang bersifat obligate intracellular, parasit ini menyerang sel epitel dan kelenjar pada saluran pencernaan (Dennis, 2014). Spesies Eimeria yang teridentifikasi menyerang 
pada ternak sebanyak 20 spesies dengan 13 spesies menyerang ternak sapi, yaitu Eimeria zuernii, Eimeria bovis, Eimeria auburnensis, Eimeria cylindrical, Eimeria illinoisensis, Eimeria subspherica, Eimeria pellita, Eimeria ellipsoidalis, Eimeria Canadensis, Eimeria bukidnonensis, Eimeria wyomingensis, Eimeria brasiliensis, dan Eimeria alabamensis (Raphael, Bruhn, Lopes, Demeu, \& Perazza, 2011).

Spesies patogen dari Eimeria spp. dengan tingkat patogenitas tinggi dan mampu menyebabkan kematian pada sapi khususnya usia muda adalah Eimeria zuernii dan Eimeria bovis (Koutny, Joachim, Tichy, \& Baumgartner, 2012). Sapi dewasa lebih tahan terhadap infeksi Eimeria spp. karena memiliki imunitas (tingkat kekebalan) yang cukup dan sistem kekebalan akan mudah terbentuk ketika terjadi infeksi (Heidari \& Gharekhani, 2014). Koksidiosis menyebabkan berbagai permasalahan kesehatan pada ternak dan menimbulkan kerugian ekonomi dengan kebanyakan mempunyai gejala yang bersifat subklinis (Raphael et al., 2011). Gejala klinis yang mengikuti kejadian koksidiosis antara lain anemia, diare, depresi, penurunan berat badan, kelemahan, dan penurunan nafsu makan. Morbiditas dan mortalitas pada kejadian koksidiosis memiliki tingkat yang tinggi (Pandit, 2009).

Saluran pencernaan merupakan sistem organ yang paling umum diserang pada kejadian koksidiosis. Kondisi saluran pencernaan yang rusak karena kejadian koksidiosis akan menurunkan fungsi sistem organ tersebut secara umum sehingga akan terjadi penurunan proses absorpsi nutrisi yang mengakibatkan penurunan performa dan produktivitas ternak. Gangguan tersebut akan terlihat jelas pada pedet yang ditandai dengan kondisi feses yang mempunyai tingkat kekeringan dibawah $10 \%$ serta diare eksudatif karena vili pada usus mengalami kerusakan (Marquez, 2014). Infeksi Eimeria spp. pada pedet mampu menimbulkan diare akut dengan $75 \%$ pada pedet berakhir dengan kematian (Raphael et al., 2011).

Eimeria spp. yang bersifat non patogen tidak menimbulkan kematian, namun tetap mempunyai kemampuan untuk menyebabkan kerusakan pada jaringan di saluran pencernaan sehingga menimbulkan potensi kepekaan terhadap penyakit yang lain. Strategi yang salah dalam pengendalian koksidiosis akan menimbulkan dampak peningkatan kasus koksidiosis, hal tersebut disebabkan oosista yang ada dalam suatu wilayah akan terus mencemari lingkungan dan menjadi sumber penularan bagi ternak lainnya khususnya yang berusia muda (Ekawasti \& Wardhana, 2019). Satu oosista Eimeria spp. yang mempunyai sifat pathogen mampu menimbulkan kerusakan 50 juta sel epitel usus halus. Selama infestasi didalam sel epitel, oosista akan menimbulkan peradangan dan pendarahan (haemorhagi) (Pedersen 2013).

Prevalensi kejadian kasus koksidiosis berhubungan erat dengan beberapa faktor antara lain kepadatan populasi ternak, usia ternak, kondisi perkandangan, tipe lantai kandang, sistem pemberian air minum, dan sistem pemberian pakan (Rehman et al., 2011). Kejadian koksidiosis pada ternak dipengaruhi oleh faktor luar seperti kondisi iklim serta faktor dari ternak seperti umur, ras, dan jenis kelamin (pengkajian, Pertanian, dan kali (Pengkajian, Pertanian, \& Selatan, 2005) Sapi betina lebih peka terhadap infeksi Eimeria spp. dibandingkan sapi jantan (Fitriastuti, Atikah, \& Ria, 2011). Kejadian koksidiosis lebih sering terjadi pada musim hujan dibandingkan musim kering (Dennis, 2014).

Deteksi oosista Eimeria spp. pada kejadian koksidiosis bisa dilakukan dengan menggunakan berbagai teknik mulai dari konvensional sampai dengan molekular. Metode konvensional sampai saat ini masih menjadi metode yang populer serta banyak dipergunakan di laboratorium dengan mengamati bentuk morfologi, warna, serta ukuran oosista yang dijumpai pada sampel feses (Ekawasti \& Wardhana, 2019). Metode kuantitatif digunakan untuk menghitung jumlah oosista Eimeria spp. per gram sampel feses (OPG) (Mundt, Bangoura, Rinke, Rosenbruch, \& Daugschies, 2005).

Sapi perah di Jember menjadi salah satu komoditas peternakan yang dikembangkan oleh peternak dengan populasi 1527 ekor pada tahun 2017 (BPS Jawa Timur, 2017) dan hingga saat ini belum ada data update tentang gambaran koksidiosis yang terjadi pada sapi perah. Penelitian ini bertujuan untuk memperoleh gambaran kejadian koksidiosis khususnya pada sapi perah di Jember. Hasil dari penelitian ini akan memberikan manfaat tentang prevalensi kejadian koksidiosis pada sapi perah di Jember sehingga 
bisa menjadi salah satu data yang bisa digunakan untuk perencanaan dalam pemberantasan penyakit parasit pada sapi perah di Jember.

\section{MATERI DAN METODE}

\section{Materi Penelitian}

Sampel diambil secara acak dari 75 ekor sapi perah Peranakan Friesian Holstein berjenis kelamin betina dengan umur yang bervariasi di Kabupaten Jember. Alat yang digunakan dalam pengambilan dan preparasi sampel adalah pot sampel $10 \mathrm{~g}$, masker, kertas label, sarung tangan plastik panjang, coolerbox, lemari pendingin, dan bordmarker permanen. Alat yang digunakan dalam pengamatan (identifikasi) oosista Eimeria spp. dan penghitungan jumlah oosista per gram sampel (OPG) adalah pipet tetes, timbangan, mortar, saringan, beker glass $100 \mathrm{ml}$, batang pengaduk, tisu, tabung sentrifus, rak tabung, sentrifus, object glass, deck glass, mikroskop binokuler, dan kamar hitung Mc. Master. Bahan yang digunakan sampel feses, garam jenuh $(\mathrm{NaCl}$ jenuh), dan akuades.

\section{Metode Penelitian}

Penelitian observasi ini menggunakan metode cross sectional pada sapi perah Peranakan Friesian Holstein berjenis kelamin betina sebanyak 75 ekor. Pengambilan sampel feses dilakukan secara acak. Kegiatan dalam proses penelitian ini terdiri dari 3 kegiatan yaitu pengambilan sampel feses, identifikasi oosista Eimeria spp. secara kualitatif, dan penghitungan jumlah oosista Eimeria spp. per gram feses (OPG) kemudian data-data yang dihasilkan dianalisis secara deskriptif dan dihitung prevalensinya.

\section{Pengambilan sampel feses}

Sampel feses diambil langsung dari rectum ternak sapi perah Friesian Holstein atau diambil dari lantai kandang apabila sapi perah baru saja mengeluarkan feses (feses segar). Pengambilan sampel dilakukan sebanyak satu kali dalam satu periode koleksi. Sampel feses yang diambil untuk setiap sapi perah adalah $10 \mathrm{~g}$ feses. Sampel feses kemudian dimasukkan ke dalam pot sampel dan diberi label serta dimasukkan dalam coolerbox. Sampel jika tidak langsung dilakukan pengujian dilakukan penyimpanan pada suhu $4^{\circ} \mathrm{C}$.

\section{Identifikasi oosista Eimeria spp.}

Identifikasi oosista Eimeria spp. dilakukan secara kualitatif dengan menggunakan metode apung atau flotation method. Sampel feses yang dibutuhkan dalam uji apung ini adalah sebanyak 2 gram. Sampel feses tersebut kemudian ditambah dengan garam jenuh $(\mathrm{NaCl}$ jenuh) sebanyak $30 \mathrm{ml}$ yang dimasukkan ke dalam mortar, setelah itu dilakukan pengadukan agar homogen. Larutan yang dihasilkan kemudian disaring dan dimasukkan ke dalam tabung sentrifugasi dengan volume $15 \mathrm{ml}$ dan dilakukan sentrifus dengan kecepatan $1.500 \mathrm{rpm}$ selama 5 menit. Tabung sentrifus diangkat kemudian diletakkan ke rak tabung dan ditambahkan garam jenuh pada permukaan larutan sampai membentuk permukaan cembung. Kemudian deck glass diletakkan pada permukaan cembung tadi, cairan yang menempel pada deck glass diperiksa di bawah mikroskop untuk melihat dan mengidentifikasi secara morfologi ada tidaknya oosista Eimeria spp. (Pusarawati, Suhintam, Ideham, Bariah, Kusmartisnawati, Tantular, Indah S., Basuki, 2013).

\section{Penghitungan jumlah oosista per gram feses (OPG)}

Penghitungan jumlah oosista Eimeria spp. per gram feses (kuantitatif) dilakukan dengan menggunakan metode Mc. Master dan Whitlock (Zajac, \& Conboy, 2007). Sampel feses yang teridentifikasi terdapat oosista Eimeria spp. pada pemeriksaan kualitatif diambil sebanyak $2 \mathrm{~g}$ dan dihancurkan menggunakan mortar kemudian ditambahkan garam jenuh ( $\mathrm{NaCL}$ jenuh) sebanyak $58 \mathrm{ml}$ dan dihomogenkan. Larutan yang dihasilkan disaring dan ditempatkan di beaker glass. Filtrat hasil penyaringan diambil menggunakan pipet tetes dan dimasukkan ke dalam kamar hitung (kaca) Mc. Master, dibiarkan selama 5 menit. Setelah itu dilakukan menggunakan mikroskop (perbesaran 10X10) dan dihitung jumlah oosista yang terdapat pada kamar hitung Mc. Master.

\section{Analisis data}

Data-data yang diperoleh kemudian dianalisis menggunakan analisis deskriptif. Prevalensi dihitung menggunakan acuan rumus dari Soulsby (1969) sebagai berikut:

Pravelensi $=\frac{\text { jumlah sampel yang terinfeksi }}{\text { jumlah sampel yang diperiksa }} \times 10$ 


\begin{tabular}{|c|c|c|}
\hline No. & Nomor Sampel & Identifikasi \\
\hline 1 & $\begin{array}{l}18,19,20,26,27,31,40,50,60,63 \\
67,69,70,73,75\end{array}$ & $\begin{array}{l}\text { Oosista } \\
\text { Eimeria spp. }\end{array}$ \\
\hline 2 & $\begin{array}{l}1,2,3,4,5,6,7,8,9,10,11,12,13, \\
14,15,16,17,21,22,23,24,25,28, \\
29,30,32,33,34,35,36,37,38,39, \\
41,42,43,44,45,46,47,48,49,51, \\
52,53,54,55,56,57,58,59,61,62, \\
64,65,66,68,71,72,74\end{array}$ & Negatif \\
\hline
\end{tabular}

\section{HASIL DAN PEMBAHASAN}

Hasil pemeriksaan kualitatif ditemukan oosista Eimeria spp. pada 15 sampel dari total sampel 75 sampel feses (Tabel 1). Hasil pemeriksaan sampel feses pada sampel nomor 18 , $19,20,26,27,31,40,50,60,63,67,69,70,73$, dan 75 ditemukan oosista dengan morfologi berbentuk ovoid, warna kuning muda dengan permukaan dinding halus, dan terdapat 4 sporosista didalam oosista yang sudah bersporulasi. Morfologi tersebut identik dengan ciri morfologi dari oosista Eimeria spp. seperti yang dijelaskan oleh Ekawasti \& Wardhana, (2019) Oosista Eimeria spp. berbentuk bulat, ovoid dan elips dengan permukaan dinding oosista halus, homogen, dan transparan. Umumnya oosista tidak berwarna, namun beberapa diantaranya mempunyai warna kuning muda. Taryu (2015) mengidentifikasi morfologi oosista dengan metode konvensional pada kejadian koksidiosis pada ternak di Sekolah Peternakan Rakyat (SPR) Bojonegoro. Koksidiosis pada ternak di SPR disebabkan oleh spesies Eimeria bukidnonensis, Eimeria Canadensis, Eimeria auburnensis, Eimeria wyomingensis, Eimeria pellita, Eimeria brasiliensis, Eimeria ellipsoidalis, Eimeria bovis, Eimeria zuernii, dan Eimeria subsperica.

Persentase sapi perah sampel yang teridentifikasi ditemukan oosista Eimeria spp. di Kabupaten Jember mencapai 20\% (15/75) (Gambar 1). Hal ini dapat disebabkan oleh pemeliharaan yang dilakukan dikandang yang dapat menghambat terjadinya koksidiosis. Risiko pravelensi infeksi Eimeria spp. lebih tinggi pada sapi yang digembalakan dibandingkan dikandangkan, dan kandang sapi perah betina selalu dibersihkan saat pemerahaan. Pola manajemen pemeliharaan dan perkandangan juga sangat mempengaruhi angka prevalensi kejadian koksidiosis, seperti kepadatan kandang, kepadatan populasi di area pengembalaan,

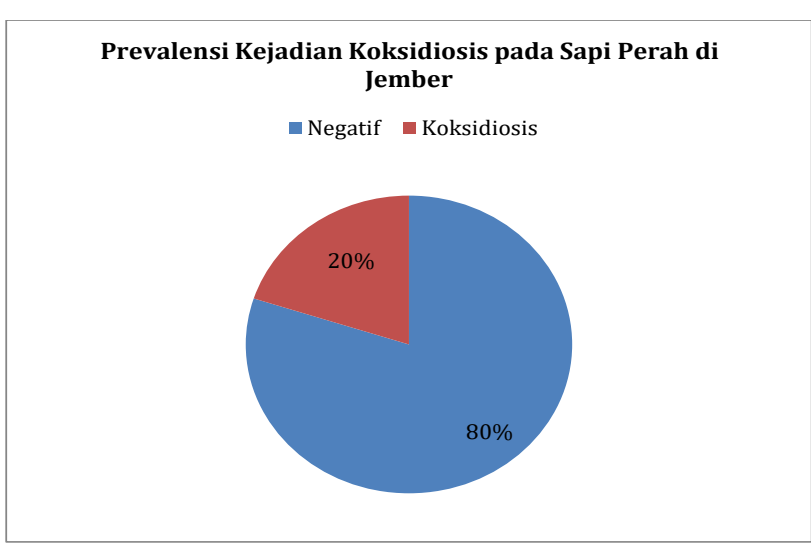

Gambar 1. Prevalensi kejadian koksidiosis pada sapi perah di Kabupaten Jember.

kadar oksigen dan pencahayaan dalam kandang, sanitasi, drainase, sistem pemberian pakan, dan sumber air minum (Bangoura, et al, 2012).

Thienpont, Rochette, \& Vanparijs, (2003) mengkategorikan bahwa infeksi ringan (slight infection) adalah berkisar antar 1 sampai 500 per gram (+), infeksi sedang (moderate infection) berkisar antara 500-5000 per gram (++), dan infeksi berat (heavy infection) lebih dari 5000 per gram $(+++)$. Hal tersebut memberikan gambaran prevalensi kejadian koksidiosis pada sapi perah di kabupaten Jember yang masih tergolong ringan dibandingkan daerah lainnya. Agung et al., (2017) melaporkan bahwa protozoa penyebab koksidiosis pada sapi di Nusa Penida adalah dari spesies Eimeria auburnensis dan Eimeria bovis dengan prevalensi mencapai 12\%. (Ekawasti \& Wardhana, 2019) menyampaikan kejadian prevalensi koksidiosis di Banten yaitu pada pedet mencapai $63,9 \%$, sapi dengan umur antara 1 -2 tahun mencapai $75 \%$, dan sapi berumur lebih dari 2 tahun mencapai $42,3 \%$. Spesies yang teridentifikasi sebagian besar adalah dari spesies Eimeria bovis dan Eimeria zuerni.

Prevalensi koksidiosis yang tidak tergolong tinggi di Kabupaten Jember tidak bisa diartikan bahwa resiko penyebaran dan peningkatan kasus koksidiosis tidak akan bisa meningkat, karena banyak faktor yang berperan dalam penyebaran koksidiosis pada sapi perah disamping tingkat ketahanan oosista di lingkungan yang bisa bertahan lama sehingga tetap harus diwaspadai dan perlu diberikan perhatian lebih untuk mencegah penyebarannya. Faktor dalam manajemen pemeliharaan, pengolahan limbah, sanitasi, dan lingkungan mempunyai peranan dalam kejadian koksidiosis. Pemeliharaan pada 
sapi perah di Kabupaten Jember yang lebih intensif sehingga pada saat pemerahan kandang selalu bersih sehingga mengurangi resiko penyebaran koksidiosis. Matsubayashi et al., (2009) menjelaskan bahwa koksidiosis pada sapi bisa meningkat karena faktor lingkungan yang meliputi musim serta iklim sehingga berpengaruh pada suhu dan kelembaban. Manajemen pemeliharaan juga mempunyai pengaruh dalam prevalensi kejadian koksidiosis. Kejadian koksidiosis lebih sering terjadi pada musim dingin atau hujan karena pada musim tersebut memiliki kelembaban dan suhu yang ideal untuk proses sporulasi dari oosista sehingga menjadi infektif (Keeton \& Navarre, 2018). Oosista Eimeria spp. pada fase infektif (sporulated oocysts) mampu bertahan pada waktu yang lama pada kondisi lingkungan yang baik maupun ekstrim (Agung et al., 2017). Kejadian infestasi Eimeria spp. pada sapi dikandangkan juga memiliki potensi resiko yang besar jika menggunakan lantai kandang tidak permanen (tanah) dibandingkan pada sapi yang dikandangkan dengan lantai kandang yang disemen (plester) (Bangoura et al., 2012).

Hasil pemeriksaan kuantitatif didapatkan bahwa jumlah dari oosista Eimeria spp. per gram (OPG) berkisar antara 5 sampai dengan 150 OPG seperti yang disajikan pada Tabel 2. Pemeriksaan secara kuantitatif dilakukan untuk memberikan gambaran terhadap derajat infeksi atau tingkat keparahan dari kejadian koksidiosis. Mundt et al (2005) menjelaskan bahwa metode kuantitatif digunakan untuk memberikan gambaran terhadap tingkat keparahan dari kejadian koksidiosis pada suatu individu dari ternak. Hasil rata-rata dari jumlah oosista Eimeria spp. per gram feses (OPG) dari 15 sampel adalah 55,67 OPG seperti yang disajikan pada Tabel 2. Hal tersebut memberikan gambaran bahwa derajat infeksi atau tingkat keparahan dari kejadian koksidiosis yang ada di Kabupaten Jember tergolong dalam katagori ringan. Thienpont et al., (2003) mengkategorikan infeksi ringan (slight infection) adalah berkisar antar 1 sampai 500 per gram (+). Sapi sampel yang terdapat oosista Eimeria spp. tidak menunjukan gejala klinis koksidiosis, hal tersebut dapat dimungkinkan karena derajat infeksi masih dalam kategori ringan sehingga kejadian penyakit berlangsung subklinis. Menurut Fitriastuti, Atikah, \& Ria, (2012) kejadian koksidiosis pada sapi betina di Indonesia umumnya mempunyai derajat infeksi yang ringan. Koksidosis pada sapi
Tabel 2. Jumlah oosista Eimeria spp. per gram feses.

\begin{tabular}{ccc}
\hline No. & Nomor Sampel & $\begin{array}{c}\text { Oosista per } \\
\text { gram (OPG) }\end{array}$ \\
\hline 1 & 18 & 50 \\
2 & 19 & 10 \\
3 & 20 & 20 \\
4 & 26 & 100 \\
5 & 27 & 50 \\
6 & 31 & 20 \\
7 & 40 & 5 \\
8 & 50 & 100 \\
9 & 60 & 50 \\
10 & 63 & 75 \\
11 & 67 & 50 \\
12 & 69 & 5 \\
13 & 70 & 100 \\
14 & 73 & 50 \\
15 & 75 & 150 \\
\hline & & 55,67 \\
\hline
\end{tabular}

perah sering dijumpai bersifat ringan dikarenakan sistem pemeliharaan pada sapi perah yang lebih intensif dan sistem perkandangan yang lebih bagus dibandingan pada sapi potong sehingga kebersihan dan asupan nutrisi lebih bagus dan berpengaruh pada terbatasnya penyebaran oosista serta ketahanan tubuh ternak sapi perah.

\section{KESIMPULAN}

Prevalensi kejadian koksidiosis pada sapi perah Friesian Holstein betina di kabupaten Jember adalah $20 \%$ dengan derajat infeksi masuk kategori ringan.

\section{DAFTAR PUSTAKA}

Agung, A., Indraswari, S., Suwiti, N. K., Ayu, I., Apsari, P., Veteriner, H., ... Universitas, V. (2017). Protozoa Gastrointestinal: Eimeria Auburnensis dan Eimeria Bovis Menginfeksi Sapi Bali Betina Di Nusa Penida. Buletin Veteriner Udayana, 9(1), 112-116. https:// doi.org/10.21531/bulvet.2017.9.1.112

Bangoura, B., Mundt, H. C., Schmäschke, R., Westphal, B., \& Daugschies, A. (2012). Prevalence of Eimeria bovis and Eimeria zuernii in German cattle herds and factors influencing oocyst excretion. Parasitology 
Research, 110(2), 875-881. https://doi. org/10.1007/s00436-011-2569-z

BPS Jawa Timur. (2017). Populasi ternak menurut kabupaten kota dan jenis ternak di Provinsi Jawa Timur 2017. https://jatim.bps.go.id/ linkTabelStatis/view/id/59.

Dennis, N. (2014). A Study of Factors Associated With the Prevalence of Coccidia.

Ekawasti, F., \& Wardhana, A. H. (2019). Coccidiosis Disease in Cattle in Indonesia and Development of Diagnostic Techniques. Indonesian Bulletin of Animal and Veterinary Sciences, 29(3), 133. https:// doi.org/10.14334/wartazoa.v29i3.2010

Fitriastuti, E. R; Atikah, N.,; Ria, N. M. (2012). Studi penyakit koksidiosis pada sapi betina di 9 Provinsi di Indonesia Tahun 2011.

Heidari, H., \& Gharekhani, J. (2014). Detection of Eimeria species in Iranian native cattle Jamal Gharekhani Result : 2(7), 731-734.

Keeton, S. T. N., \& Navarre, C. B. (2018). Coccidiosis in Large and Small Ruminants. Veterinary Clinics of North America - Food Animal Practice, 34(1), 201-208. https://doi. org/10.1016/j.cvfa.2017.10.009

Koutny, H., Joachim, A., Tichy, A., \& Baumgartner, W. (2012). Bovine Eimeria species in Austria. Parasitology Research, 110(5), 1893-1901. https://doi.org/10.1007/s00436-0112715-7

Lassen, B., Lepik, T., \& Järvis, T. (2014). Seasonal recovery of Eimeria oocysts from soil on naturally contaminated pastures. Parasitology Research, 113(3), 993-999. https://doi.org/10.1007/s00436-0133731-6

Marquez, J. C. (2014). Calf Intestinal Health: Assemesnt and Dietary Interventions for Its Improvement. XXXIII(2), 8187. Retrieved from http://www. americanbanker.com/issues/179_124/ which-city-is-the-next-big-fintech-hubnew-york-stakes-its-claim-1068345-1. html\%5Cnhttp://www.ncbi.nlm.nih. gov/pubmed/15003161\%5Cnhttp://cid. oxfordjournals.org/lookup/doi/10.1093/ cid/cir991\%5Cnhttp://www.scielo

Matsubayashi, M., Kita, T., Narushima, T., Kimata, I., Tani, H., Sasai, K., \& Baba, E. (2009). Coprological survey of parasitic infections in pigs and cattle in slaughterhouse in Osaka, Japan. Journal of Veterinary Medical Science, 71(8), 1079-1083. https://doi. org/10.1292/jvms.71.1079

Mundt, H. C., Bangoura, B., Rinke, M., Rosenbruch, M., \& Daugschies, A. (2005). Pathology and treatment of Eimeria zuernii coccidiosis in calves: Investigations in an infection model. Parasitology International, 54(4), 223-230. https://doi.org/10.1016/j. parint.2005.06.003

Pandit, B. A. (2009). Prevalence of Coccidiosis in Cattle in Kashmir valley. 4(1), 2-5.

Pedersen S. 2013. Coccidiosis in cattle and sheep control and management methods. Sptlight Pars Diss. 1:18-19.

Pengkajian, B., Pertanian, T., \& Selatan, K. (2005). Potensi Lahan Rawa Di Kalimantan Selatan. 201-207.

Pusarawati, Suhintam, Ideham, Bariah, Kusmartisnawati, Tantular, Indah S., Basuki, S. (2013). Atlas parasitologi kedokteran. Jakarta: EGC.

Raphael, F., Bruhn, P., Lopes, M. A., Demeu, F. A., \& Perazza, C. A. (2011). Frequency of species of Eimeria in females of the holstein - friesian breed at the post-weaning stage during autumn and winter. 2961, 303-307.

Rehman, T. U., Khan, M. N., Sajid, M. S., Abbas, R. Z., Arshad, M., Iqbal, Z., \& Iqbal, A. (2011). Epidemiology of Eimeria and associated risk factors in cattle of district Toba Tek Singh, Pakistan. Parasitology Research, 108(5), 1171-1177. https://doi.org/10.1007/ s00436-010-2159-5

Soulsby, E. J. L. (1969). Helminths, Arthropods and Protozoa of Domesticated Animals (7 rd). London: The English Language Book Society and Bailliere Tindal.

Taryu. (2015). Koksidiosis pada sapi potong di sekolah peternakan rakyat (spr) kecamatan kasiman kabupaten bojonegoro (Thesis). Bogor (Indonesia): Institut Pertanian Bogor.

Thienpont, D., Rochette, F., \& Vanparijs, O. F. J. (2003). By Coprological Examination. (January), 110p.

Zajac, A.Z., \& G. A. C. (2007). Veterinary Clinical Parasitology, 7th ed. In The Canadian Veterinary Journal. la Revue Veterinaire Canadienne (Vol. 48). 